The Geographical Journal of Nepal

Vol. 15: 41-62, 2022

DOI: https://doi.org/10.3126/gjn.v15i01.42886

Central Department of Geography,

Tribhuvan University, Kathmandu, Nepal

\title{
Land evaluation for land use planning in Sambhunath municipality of Saptari district, Nepal
}

\author{
Bikash Kumar Karna ${ }^{1}$, Shobha Shrestha ${ }^{2 *}$, Hriday Lal Koirala ${ }^{2}$ \\ ${ }^{1}$ Survey Department, Government of Nepal \\ ${ }^{2}$ Central Department of Geography, Tribhuvan University \\ * Corresponding author: shova216@gmail.com
}

Received: 19 September, 2021; Accepted: 21 October, 2021; Published: March, 2022

\begin{abstract}
Dynamics of land use are closely related with society, development activities and environment. For the sustainable management of land resource of an area, land use may act as one of the elements of conflicts which could be resolved through land use planning ensuring equitable access and right of land to the owners. The present paper attempts to assess the land use for land use planning and infrastructure development through land evaluation including risk factors. Sambhunath municipality located within Saptari district of Nepal has been used as the study area to test the issues raised. Both qualitative and quantitative methods are used for data generation and analysis. Land use changes have been analyzed for the period 1986 to 2017. Potential land use zones have been identified through land suitability analysis using MCE-AHP and in relation to the risk factors such as flood, soil erosion, landslide, and fire. The infrastructure development plan has been allocated based on land use suitability index maps and planning guidelines. Land use projection have been made through Cellular Automata technique, and land use plans have been developed based on projected land use and optimized through SWOT analysis. Implementation strategy is developed based on legal framework to implement land use plan at local level. The land use change patterns are characterized by the increase of agriculture and built-up area and the decrease in areas under forest cover and water body simultaneously. Altogether 27 different criteria are identified and applied in land use suitability evaluation. Risk prone area is found mostly surrounding to the foot of Chure hill and along Khando river. Almost $46 \%$ of the total areas have been planned for future agriculture land use followed by residential, commercial, industrial and public uses which are $201 \mathrm{ha}, 26 \mathrm{ha}$, 3ha, and 345 ha respectively. An implementation strategy has been devised to empower and enforcement for compliance of land use zone together with guidelines for outlined development activities.
\end{abstract}

Keywords: Land use planning, land evaluation, MCE, AHP and GIS. 


\section{Introduction}

Land is the basic precious natural resources on the earth surface that support the life for food, fodder, fiber, fuel, timber and other biotic materials for human beings (FAO, 1995). It also provides shelters, filters and stores water and supplies space for urban and industrial development (Verheye, 2009); sources of nutrition, income and employment, and the basis for security, status, social identity and political relations (Veit, 2011); integrating components of all livelihoods depending on farm, forest, rangeland, or water (rivers, lakes, coastal marine) habitats. The land is limited in extent and particularly the cultivable land is finite (Verheye, 2009) therefore, a proper land use planning with the appropriate land evaluation scheme is necessary in an area for the sustainable development.

Land use (LU) denotes the human activity associated with a specific piece of land and mainly refers to the use by human beings for specific purposes with some sorts of management practices (Khanal, 2000). Land use is influenced by different factors such as the physiographic, topographic, climatic, lithology, soil type, climate, rainfall pattern, settlement pattern, cultural and traditional practices, and socio-economic factors, etc. Land use planning is the systematic and iterative process in order to create an enabling environment for sustainable development of land resources which meets people's needs and demands (GIZ, 2011). The planning process assesses the physical, socioeconomic, institutional and legal potentials and constraints with respect to the optimal and sustainable use of land resources, and empowers people to make decisions about how to allocate those resources (FAO \& UNEP, 1999). The implementation strategy of land use planning is a guideline document as legal provisions for land development and its proper use. These legal provisions assist to enforce the implementation of land use plan and its monitoring process for sustainable land management in the planning area.

Now-a-days, land use planning is widely used with integration with land evaluation technique using geographic information system (GIS) and remote sensing (Widiatmaka, 2016). GIS and its tool are mostly useful for spatial analysis in land evaluation having capability for acquisition, storage and extraction of land and related land use information (Mendas \& Delali, 2012; Widiatmaka, 2016). Remote sensing (RS) technique is used to collect massive spatial information quickly in the real-time. RS data coupled with fieldwork information and GIS are recognized as an effective tool in qualitative and quantitatively measuring spatial pattern and its change at a relatively large geographic scale (Nigam, 2006). Multi-criteria evaluation (MCE) is well suited tool and the most useful applications of GIS in planning process (Malczewski, 2004; Widiatmaka, 2016). Generally, it is used to identify a single most preferred option, to rank option, to short-list a limited number of options for subsequent detailed appraisal to distinguish acceptable all possibilities (Dodgson et al., 1999). Analytical hierarchy process (AHP) is one of the outranking-based decision-making method (Ishizaka et al., 2017) and widely applied in MCE based land evaluation process. These techniques could be applied to model the land evaluation for land use planning of the country. 
Despite these available technical options on the evaluation of land for the land use planning, to the best of our knowledge, we have found no single attempt has been made so far in Nepal. A lot of studies have been made on the analysis of land use and temporal change pattern in different localities within the country and outside (Weng, 2002; Zubair, 2006; Long et al., 2007; Paudel 2008; Wu et al., 2009; Khanal, 2002; Paul, 2013; Liu et al., 2014; Ziadat \& Al-Bakari, 2006; KC, 2015; Chaikaew, 2019 as cited in Karna, 2021). These land use studies are limited to specific changes of land use as well as the causative driving factors for the changes. Similarly, on the issues of land evaluation, the available studies (Dia et al., 2008; Yang et al., 2008; Jafari \& Zaredar, 2010; Nyeko, 2012; Hao, 2013 as cited in Karna, 2021) have analyzed specific areas using different parameters such as physical, social, economic, environmental and utilities/facilities of suitability of different land use. None of the studies have incorporated associated risk factors such as flood, landslide, soil erosion and fire etc.

Likewise on the issues of optimal land use plan, the available studies (Trung et al., 2006; Lingjun et al., 2008; Hao, 2013; Ullah \& Mansourian, 2015; Gormus et al., 2017 as cited in Karna, 2021) have assessed the urban-rural land use planning using land suitability evaluation and decision making process through MCE-AHP tool. However, there is still a lack of knowledge to explore whether it is possible to model a land use planning in an implementable format within an area or a country. Similarly, some of the researches (Reginster \& Rounsevell, 2006; Yu et al., 2011; Nyeko, 2012; BojorquezTapia et al., 2001; Trung et al., 2006; Hessel et al., 2009; and Zolkafli et al., 2017 as cited in Karna, 2021) have used decision making process and participatory planning in land use planning. However, there are still lack of the studies to incorporate the risk factors and physical development plan within land use planning process. Further, none of the previous studies have attempted to develop implementation strategy. It is in the context, the present paper attempts to fill the research gap. It assesses the land use for land use planning and infrastructure development through land evaluation selecting Sambhunath municipality of Saptari district as the study area.

\section{The study area}

The study area, Sambhunath municipality is located at the latitude between $26^{0} 23^{\prime} 35^{\prime \prime}$ to $26^{\circ} 42^{\prime} 36^{\prime \prime}$ and longitude between $86^{\circ} 37^{\prime} 39^{\prime \prime}$ to $86^{\circ} 44^{\prime} 54^{\prime \prime}$ in Sapatari District of Province 2 (Figure 1). Previously, Sambhunath was one Village Development Committee (VDC) at local level and upgraded into municipality on $18^{\text {th }}$ May, 2014 through a merger of previous VDCs namely Khoksar Parbaha, Shambhunath, Mohanpur, Bhangha, Basbalpur, Rampur Jamuwa and Arnaha (Karna, Shrestha \& Koirala, 2021). The total area of the municipality is $108.46 \mathrm{sq} . \mathrm{km}$. and is divided into 12 wards as its sub-administrative unit. The municipality office is located at Kathauna Bazar. The municipality has a total population of 38018 in which male are 18112 and female are 19906 in 2017 (MoFAGA, 2018) distributing with average household size of 
5.21. The overall literacy rate is 54.32 percent with male 66.36 percent and female 43.52 percent in the municipality. In religious composition; majority population are Hindu (91 percent) followed by Muslim ( 6 percent), Buddhism ( 1 percent) and remaining 2 percent as others.

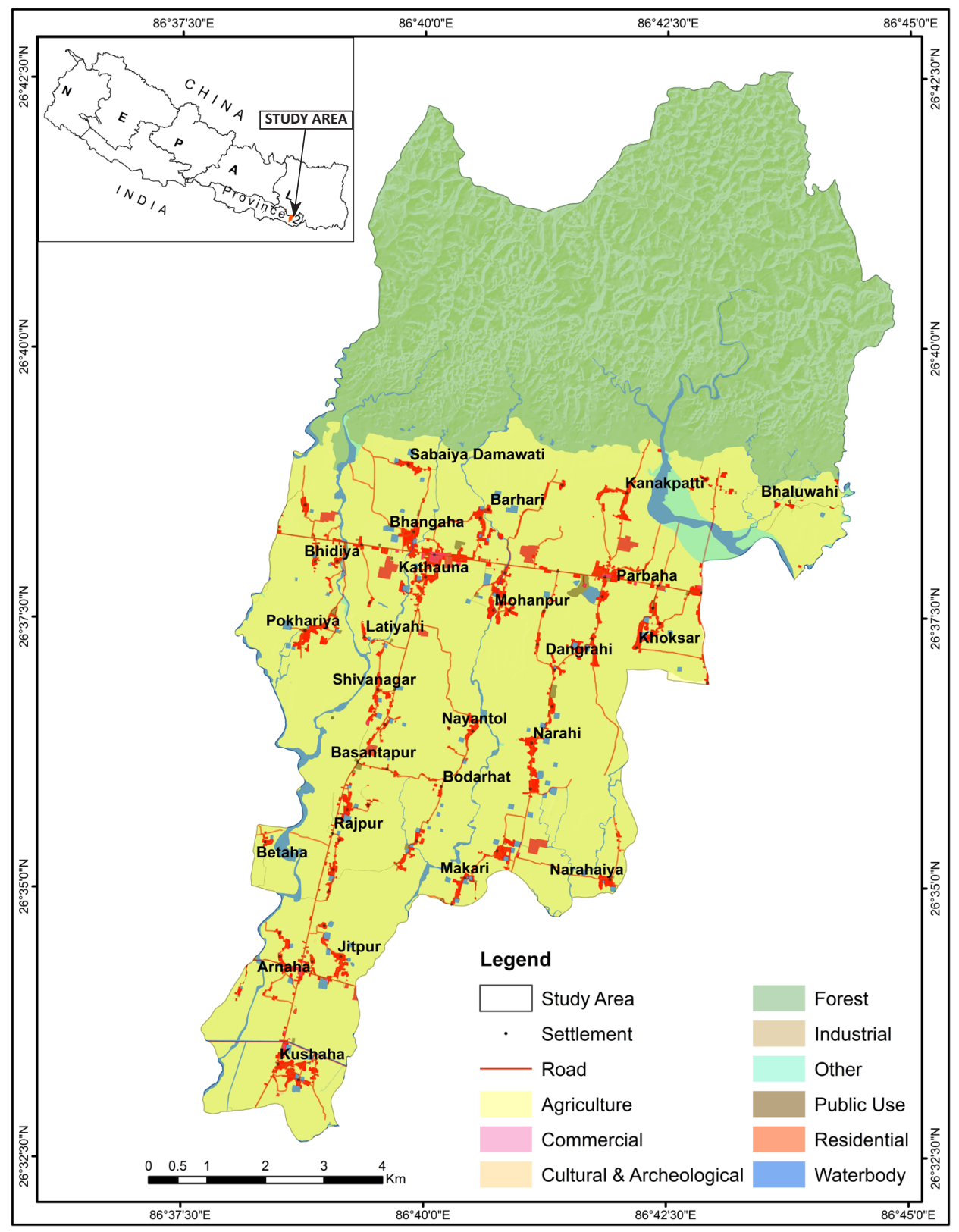

Figure 1: The study area 


\section{Methods adopted}

This paper is based on the primary data collected from field visit and observation, rapid rural appraisal and participatory rural appraisal, expert interview, and focus group discussion carried out in 2019. However, available and relevant secondary data/ information has also been used. Both the combination of qualitative and quantitative methods and techniques was adopted in holistic view for the analysis of land use pattern, identification of parameters, spatial modelling for risk layers, land evaluation

for land use class, projection of land use, and preparation of optimal land use plan with its implementation strategies.

The land utilization map of Survey Department of Nepal has been used to generate a base year land use map of 1986. In the same way, the topographical map sheets prepared by Survey Department have also been to produce land use data/map for 1996. Finally, the land use data/map for 2017 has been prepared based on the analysis and interpretation of WorldView-2 satellite image using supervised image classification technique with maximum likelihood classifier (MLC) algorithm. Land use change analysis from 1986 to 2017 was analysed through spatial overlay technique and quantification with geospatial tools.

In order to land suitability evaluation, altogether 27 different criteria have been identified from the existing literatures, and those criteria were contextualized after a thorough discussion with the experts and stakeholders to use in local situation. Likewise, risk factors such as flood, soil erosion, landslide, and fire risk are identified as the constraints in land use planning and the potential areas under risk factors have been evaluated through GIS based analysis and modelling. Similarly, land suitability evaluation has been conducted with integration of GIS tools and MCE which identified suitable sites for specific land use such as agriculture, residential, commercial, industrial, and forest based on the selected criteria and computing the weight of criteria through AHP process.

The planning guideline has been developed based on a strategic plan of 20 years with development targets that prerequisites to achieve. Infrastructure development plan has been made based on land use suitability index map and planning guideline that meet the needs of local people for basic physical infrastructure, land use change and its growing trend. Land use projection is obtained through cellular automata (CA) simulation technique. The projected land use data has been used in decision making process of land use planning to allocate best land use options (Schreinemachers \& Berger, 
2006). Land use plan has been developed based on projected land use incorporating infrastructure development and risk layers, and it has been qualitatively optimized through SWOT (strength, weakness, opportunity, and threat) process. Finally, the land use implementation strategy has been developed based on the existing legal provisions as well as reference to the international practice. It is anticipated that the developed strategy would be feasible to implement optimal land use at local level and would act as development code.

\section{Results and discussion}

\section{Land use pattern}

Land use maps and the changes in land use area from 1986 to 1996 show a different picture for different land use class (Table 1 and Figure 1). In nut shell, there is an increase in agricultural land area contributing from forest, barren and bush area particularly along the north of East-west highway, despite a decrease of 351 ha during 1996 to 2017 period. Similarly, the residential land area has also been increased by 35 ha particularly along the two distinct spaces: the one along East-west highway and the other along Kathauna to Pato feeder road. In the same way, the areas under commercial, industrial, cultural and archaeological sites have also been increased to a small extent. However, in overall there has been decrease in area under water body due to the construction of embankment and expansion of agriculture practices in the lowland surroundings of the Khando river though there has been increase in area by 160 ha along the Khando river due to the flood and siltation in the agriculture land during 1996 to 2017 period. The areas under public use land shows an initial decrease which was mainly due to the encroachment for agriculture practices along road corridor and for residential purposes in the settlement surrounding. However, the areas under public use started to increase in later part gradually from 1986 to 2017. It is resulted for haring due to the construction of roads in different parts of the municipality connectivity with major roads to the settlement areas known as villages. 
Table 1: Land use and temporal changes

\begin{tabular}{|l|r|r|r|r|r|r|}
\hline \multirow{2}{*}{$\begin{array}{c}\text { Land use } \\
\text { categories }\end{array}$} & \multicolumn{3}{|c|}{ Area change in hectares } & \multicolumn{3}{c|}{ Area change in percentage } \\
\cline { 2 - 7 } & $1986-1996$ & $1996-2017$ & $1986-2017$ & $1986-1996$ & $1996-2017$ & $1986-2017$ \\
\hline Agriculture & 1193.20 & -351.06 & 842.14 & 25.03 & -5.89 & 17.67 \\
\hline Forest & -141.83 & 6.47 & -135.36 & -3.13 & 0.15 & -2.98 \\
\hline Other & -772.85 & 34.95 & -737.89 & -70.84 & 10.99 & -67.64 \\
\hline Water body & -303.34 & 159.71 & -143.63 & -76.96 & 175.87 & -36.44 \\
\hline Residential & 35.39 & 30.64 & 66.03 & 101.28 & 43.57 & 188.97 \\
\hline Public Use & -13.63 & 71.65 & 58.02 & -40.06 & 351.28 & 170.49 \\
\hline Commercial & 1.97 & 37.61 & 39.58 & 386.78 & 1518.65 & 7779.32 \\
\hline $\begin{array}{l}\text { Cultural \& } \\
\text { Archeological }\end{array}$ & 0.86 & 7.87 & 8.72 & 303.59 & 690.14 & 3088.90 \\
\hline Industrial & 0.23 & 2.15 & 2.39 & 173.28 & 584.95 & 1771.80 \\
\hline
\end{tabular}

The analysis of land use changes from 1986 to 2017 shows a high increase rate in builtup area (residential, commercial and industrial) along the corridor of East-west highway, Hulaki highway, feeder roads and other strategic road networks. The commercial area has been increased mainly along the East-west highway and junction of feeder roads at Kathauna Bazar, Traffic Chowk, and Hulaki highway in Arnaha area. Due to the lack of irrigation facilities, there is a shift in agricultural practices from cereal crops to mango orchard. It has been observed particularly in the middle to northern part up to the foot of the Siwalik hill. There is an increase of 842 ha agriculture land in the north of East-west highway through deforestation and encroachment of barren and bush area.

Shannon's Entropy analysis could be used for the concentration measurement of the growth for built-up (residential, commercial and industrial) area in which the difference on entropy indicates the temporal change in the degree of dispersal in land development (Karna, Mandal \& Bhardwaj, 2013). The analysis of the entropy values in Sambhunath municipality indicates that there are fewer sprawls in the year 1986, started to increase in 1996, and substantial internal variation in the patterns of urban growth measured in 2017. The built-up area growths have been expanded near the settlement area and as sprawl fringe in the agricultural area. The proportion entropy in built-up areas has been increased rapidly by 14 percent in 1986, 24 percent in 1996 and 45 percent in 2017. The built-up area concentration projection rate has been calculated as 63 percent for 2037 A.D. 


\section{Risk zone evaluation}

Generally, risk assessment is used to reduce the vulnerability of people and infrastructure identifying appropriate and safe locations for settlement, open space and construction infrastructure as public utility services and enhancing the economic activities (ADPC, 2015). The present study has used the risks zone for the flood, soil erosion, landslide, and fire hazard risk.

For flood risk evaluation, catchment area has been determined from DEM with hydrological analysis tool in GIS environment. The discharge is defined as the flow of water volume per sec in the channel of river system and measured randomly at Khando river at East west highway in the municipality. The flow of discharge is computed for 2 years and 100 years return period based on its entire catchment area and correlated with the measured discharge data. The computed discharge data was used in simulation of flood modelling for Khando, Kajara, Juri and Mutani rivers using GIS, HEC-GeoRAS and HEC-RAS softwares. The simulation of flood inundation for 100-year return period has shown 213 ha land in high risk with a flood depth $>1.5 \mathrm{~m}, 405$ ha land in moderate risk with flood depth between $0.5 \mathrm{~m}$ to $1.5 \mathrm{~m}$, and 536 ha land are prone to low risk with flood depth $<0.5 \mathrm{~m}$ (Table 2). Almost 11 percent of the total areas of the municipality are prone to different level of flood risk in which the shares of agricultural land, forest areas, other and residential areas are 56, 11, 9 and, 1 percent respectively. Almost 13 ha of residential areas are found in the flood prone risk and hence there is urgent necessary for resettlement of these communities in safe zone.

Table 2: Flood risk impact on land use

\begin{tabular}{|c|c|c|c|c|c|c|c|c|c|}
\hline \multirow{2}{*}{ S.N. } & \multirow{2}{*}{$\begin{array}{c}\text { Land Use } \\
\text { Type }\end{array}$} & \multicolumn{2}{|c|}{ Area in Land use } & \multicolumn{5}{|c|}{ Risk Area Based on Land Use (in ha) } & \multirow{2}{*}{$\begin{array}{c}\text { Overall } \\
\text { Risk } \\
(\%)\end{array}$} \\
\hline & & (in ha) & $\%$ & High & Medium & Low & Total & $\%$ & \\
\hline 1 & Agriculture & 56 & 51.70 & 11.22 & 202.42 & 430.98 & 644.62 & 55.88 & 11.48 \\
\hline 2 & Water body & 353.16 & 3.25 & 167.62 & 76.45 & 14.18 & 258.25 & 22.39 & 73.13 \\
\hline 3 & Forest & 4402.79 & 40.54 & 0.70 & 63.51 & 66.92 & 131.13 & 11.37 & 2.98 \\
\hline 4 & Other & 100.98 & 0.93 & 33.05 & 56.09 & 10.66 & 99.80 & 8.65 & 98.83 \\
\hline 5 & Residential & 252.59 & 2.33 & 0.03 & 3.33 & 9.16 & 12.52 & 1.08 & 4.95 \\
\hline 6 & Public Use & 89.07 & 0.82 & 0.13 & 2.65 & 3.15 & 5.93 & 0.51 & 6.66 \\
\hline 7 & Industrial & 37.58 & 0.35 & 0.00 & 0.11 & 1.27 & 1.38 & 0.12 & 3.66 \\
\hline 8 & Commercial & 8.56 & 0.08 & 0.00 & 0.00 & 0.00 & 0.00 & 0.00 & 0.00 \\
\hline 9 & $\begin{array}{l}\text { Cultural \& } \\
\text { Archeological }\end{array}$ & 0.67 & 0.01 & 0.00 & 0.00 & 0.00 & 0.00 & 0.00 & 0.00 \\
\hline & Total & 10860.45 & 100.00 & 212.75 & 404.56 & 536.32 & 1153.63 & 100.00 & 10.62 \\
\hline
\end{tabular}


The high risk of soil erosion is found in areas of forests and paddy fields, bare lands, construction areas, and crop fields on slopes (Koirala, Thakuri, Joshi \& Chauhan, 2019; Karna, Shrestha \& Koirala 2021). Rainfall erosivity (R), soil erodibility (K), topography (LS), crop management (P), and conservation practice factors (C) are considered as parameters for estimation of soil loss through rainfall and surface water flow using RUSLE model. The potential soil erosion map is produced by the raster multiplication in GIS through map algebra function (Karna, Shrestha \& Koirala 2021) for Sambhunath Municipality where the soil erosion rates are measured between 0 to $2635 \mathrm{t} \mathrm{ha}^{-1} \mathrm{yr}^{-1}$ in terms of soil loss per year. The soil loss estimation has been categorized under six classes as low with lesser than $5 \mathrm{t} \mathrm{ha}^{-1} \mathrm{yr}^{-1}$, as moderate with 5-10 $\mathrm{tha}^{-1} \mathrm{yr}^{-1}$, as high with 10-20 tha $\mathrm{tr}^{-1} \mathrm{yr}^{-1}$, as very high with 20-40 $\mathrm{tha}^{-1} \mathrm{yr}^{-1}$, as sever with 40-80 $\mathrm{tha}^{-1} \mathrm{yr}^{-1}$ and as very severe with higher than $80 \mathrm{t} \mathrm{ha}^{-1} \mathrm{yr}^{-1}$ similar as defined by Koirala, Thakuri, Joshi and Chauhan (2019) for Nepal. The analysis shows that almost 7814.70 ha (72\%) of the municipality areas are within low category of soil erosion, 2562.78 ha $(23 \%)$ within higher soil loss risk and leaving rest of the areas within moderate soil loss. However, the potential impacts on soil loss rates are highly correlated with the increasing exposure of land surface. It has been observed that 3331.04 tons/ha (92\%) of the total soil losses in the municipality are from the scattered forest area of the Chure hill (Table 3). Similarly, agriculture land has the share of four percent in the total soil loss.

Table 3: Soil erosion impact on land use

\begin{tabular}{|c|c|c|c|c|c|c|c|}
\hline \multirow{2}{*}{ S.N. } & \multicolumn{3}{|c|}{ Land Use/Land Cover } & \multicolumn{4}{|c|}{ Potential Soil Loss (tons/ha) } \\
\hline & Description & Area (in ha) & $\%$ & Max & Average & Total & $\%$ \\
\hline 1 & Agriculture & 5615.05 & 51.70 & 174.83 & 0.26 & 16293.11 & 4.49 \\
\hline 2 & Forest & 4402.79 & 40.54 & 2635.78 & 6.81 & 333104.27 & 91.81 \\
\hline 3 & Water body & 353.16 & 3.25 & 202.33 & 0.44 & 1681.36 & 0.46 \\
\hline 4 & Residential & 252.59 & 2.33 & 38.69 & 0.04 & 109.58 & 0.03 \\
\hline 5 & Other & 100.98 & 0.93 & 574.72 & 10.17 & 11475.92 & 3.16 \\
\hline 6 & Public Use & 89.07 & 0.82 & 10.45 & 0.14 & 139.44 & 0.04 \\
\hline 7 & Industrial & 37.58 & 0.35 & 1.15 & 0.01 & 4.88 & 0.00 \\
\hline 8 & Commercial & 8.56 & 0.08 & 0.38 & 0.01 & 0.93 & 0.00 \\
\hline 9 & $\begin{array}{l}\text { Cultural \& } \\
\text { Archeological }\end{array}$ & 0.67 & 0.01 & 0.00 & 0.00 & 0.00 & 0.00 \\
\hline & Total & 10860.45 & 100.00 & & & 362809.50 & 100.00 \\
\hline
\end{tabular}


Landslides occur from the movement of debris, rock or soil mass down the slope (Cruden, 1991), play an important role in landform evolution and cause of a destructive natural hazards. It also occurs through the displacement of unstable masses of soil and stone through earthquakes, tectonic and seismic activities, various geological and climatic conditions, heavy rainfall and various human activities (Seyedeh, Ataollah, Karim, Seyed \& Ataollah, 2011). Landslide susceptibility mapping (LSM) is carried with statistical bivariate analysis using frequency ratio (FR) technique where the potential impact of landslide assessment was made with zonal statistics of landslide susceptibility and land use layer 2017 using spatial overlay operation (Table 4). In overall, 34 percent areas of the municipality are prone to landslide risk in which the distribution of the high risk, medium risk and low risk areas are 1, 33 and 66 percent respectively. However, most of the land slide prone areas lie within the scattered forest parts under Chure hills together with small areas near the river which requires slope protection. The area under the curve of the success rate is found as 0.88 and prediction rate as 0.89 that showing reliable with all satisfactorily validation rates having good accuracy.

Table 4: Impact of landslide risk on land use

\begin{tabular}{|c|c|c|c|c|c|c|c|c|c|}
\hline \multirow{2}{*}{ S.N. } & \multicolumn{3}{|c|}{ Land Use Type } & \multicolumn{5}{|c|}{ Landslide Susceptibility (in ha) } & \multirow{2}{*}{\begin{tabular}{|c|} 
Overall \\
Risk \\
$(\%)$
\end{tabular}} \\
\hline & Description & Area (ha) & $\%$ & High & Medium & Low & Total & $\%$ & \\
\hline 1 & Agriculture & 5615.04 & 51.70 & 0.20 & 15.23 & 1.79 & 17.22 & 0.46 & 0.31 \\
\hline 2 & Forest & 4402.67 & 40.54 & 48.57 & 2400.70 & 1218.76 & 3668.03 & 98.94 & 83.31 \\
\hline 3 & Water body & 353.163 & 3.25 & 0.23 & 15.19 & 5.98 & 21.40 & 0.58 & 6.06 \\
\hline 4 & Residential & 252.59 & 2.33 & 0.00 & 0.05 & 0.00 & 0.05 & 0.00 & 0.02 \\
\hline 5 & Other & & 0.93 & 0.00 & 0.71 & 0.00 & & 0.02 & 0.70 \\
\hline 6 & Public Use & 89.07 & 0.82 & 0.00 & 0.02 & 0.00 & 0.02 & 0.00 & 0.03 \\
\hline 7 & Industrial & 37.58 & 0.35 & 0.000 & 0.000 & 0.000 & 0.000 & 0.00 & 0.00 \\
\hline 8 & Commercial & 8.56 & 0.08 & 0.000 & 0.000 & 0.000 & 0.000 & 0.00 & 0.00 \\
\hline 9 & $\begin{array}{l}\text { Cultural \& } \\
\text { Archeological }\end{array}$ & 0.67 & 0.01 & 0.000 & 0.000 & 0.000 & 0.000 & 0.00 & 0.00 \\
\hline & Total & 10860.32 & 100.00 & 48.99 & 2431.89 & 1226.53 & 3707.42 & 100.00 & 34.14 \\
\hline
\end{tabular}

Fire incidence causes the loss of life, injury and other health impacts, property damage, loss of livelihoods and services, social and economic disruption, and environmental damage (Awasthi, 2019). Generally, the fire incidences in Nepal take place during summers in Terai areas particularly in the villages where houses are made of thatched roof as well as buildings with poor management of fire in which randomly occurred from the electric circuit malfunction in wiring and high voltage transmission line circuit breakdown can act as incidences. Fire incidence can also damage the forest resources resulting in the loss of biodiversity and deterioration of forest condition. Fire analysis was carried out in GIS environment using MCE and AHP technique with the weighted 
overlay function. In overall, 40 percent total areas of the municipality are under the fire risk in which the distribution of the high risk, medium risk and low risk are 0.13 , 1.23 and 38.21 percent respectively leaving the remaining 60 percent area free from fire hazard (Table 5). So far as the fire risk as per the different land use categories are concerned, 80 percent areas of cultural and archeological land use, 58 percent areas of residential land use, 47 percent areas of forest land use, 43 percent areas of commercial land use and 36 percent areas of agricultural land use are under the threat of fire hazard risk in Sambhunath municipality area.

Table 5: Impact of fire risk on land use

\begin{tabular}{|c|c|c|c|c|c|c|c|c|c|}
\hline \multirow{2}{*}{ S.N. } & \multicolumn{3}{|c|}{ Land Use Type } & \multicolumn{5}{|c|}{ Fire Risk Susceptibility } & \multirow{2}{*}{$\begin{array}{c}\text { Overall } \\
\text { Risk } \\
(\%)\end{array}$} \\
\hline & Description & $\begin{array}{c}\text { Area } \\
\text { (in ha) }\end{array}$ & $\%$ & High & Medium & Low & Total & $\%$ & \\
\hline 1 & Agriculture & 5615.04 & 51.70 & 12.67 & 80.39 & 1906.68 & 1999.74 & 46.54 & 35.61 \\
\hline 2 & Forest & 4402.78 & 40.54 & 0.00 & 32.62 & 2037.12 & 2069.74 & 48.17 & 47.01 \\
\hline 3 & Water body & 353.16 & 3.25 & 0.00 & 0.15 & 17.96 & 18.10 & 0.42 & 5.13 \\
\hline 4 & Residential & 252.59 & 2.33 & 1.13 & 12.21 & 132.89 & 146.23 & 3.40 & 57.89 \\
\hline 5 & Other & 100.98 & 0.93 & 0.00 & 0.77 & 14.15 & 14.92 & 0.35 & 14.78 \\
\hline 6 & Public Use & 89.07 & 0.82 & 0.22 & 3.73 & 25.22 & 29.17 & 0.68 & 32.75 \\
\hline 7 & Industrial & 37.58 & 0.35 & 0.00 & 2.07 & 12.33 & 14.41 & 0.34 & 38.33 \\
\hline 8 & Commercial & 8.56 & 0.08 & 0.00 & 1.21 & 2.49 & 3.70 & 0.09 & 43.23 \\
\hline 9 & \begin{tabular}{|l|} 
Cultural \& \\
Archeological \\
\end{tabular} & 0.67 & 0.01 & 0.00 & 0.00 & 0.53 & 0.53 & 0.01 & 79.47 \\
\hline & Total & 10860.43 & 100.00 & 14.02 & 133.15 & 4149.38 & 4296.54 & 100.00 & 39.56 \\
\hline
\end{tabular}

\section{Land use suitability evaluation}

Land use suitability evaluation has been conducted with the integration of GIS tools and MCE for suitable site of land use based on the criteria and computing the weights. The criteria used in land use suitability evaluation are identified from literatures which are based on the interrelationship between social, economic and land use and modified as per the planning perspective through interaction in focus group discussion with decision makers, stakeholders and planners. The participants of the focus group interaction agreed to select the land use classes such as agriculture, residential, commercial, industrial, and forest for the municipality (Table 6). During FGD interaction, sub-criteria of the selected criteria have been chosen based on the planning standard guidelines and regulation of land development. The 1-9 pair wise comparison rating scale is used to compare the relative importance of every two criteria in which 1 represents low suitability and 9 as the high suitability with 0.1 as limiting threshold. Based on the weight of the criteria as determined in AHP a weight linear combination (WLC) was performed to obtain the suitability of each land use class. 
Bikash Kumar Karna, Shobha Shrestha, Hriday Lal Koirala Land evaluation for... Vol. 15: 41-62, 2022

Table 6: Selected criteria for particular land use

\begin{tabular}{|c|c|c|c|c|c|}
\hline Criteria & Agriculture & Residential & Commercial & Industrial & Forest \\
\hline Slope & $\sqrt{ }$ & $\sqrt{ }$ & $\sqrt{ }$ & $\sqrt{ }$ & $\sqrt{ }$ \\
\hline Current Land Use & $\sqrt{ }$ & $\sqrt{ }$ & $\sqrt{ }$ & $\sqrt{ }$ & $\sqrt{ }$ \\
\hline $\begin{array}{l}\text { Geomorphology (Land Form \& } \\
\text { Landscape) }\end{array}$ & $\sqrt{ }$ & $\sqrt{ }$ & $\sqrt{ }$ & $\sqrt{ }$ & $\sqrt{ }$ \\
\hline Land Capability & $\sqrt{ }$ & $\sqrt{ }$ & $\sqrt{ }$ & $\sqrt{ }$ & \\
\hline Geology (Lithology) & $\sqrt{ }$ & & & & $\sqrt{ }$ \\
\hline Soil Type & $\sqrt{ }$ & & & & $\sqrt{ }$ \\
\hline Population & & $\sqrt{ }$ & $\sqrt{ }$ & $\sqrt{ }$ & \\
\hline Surrounding Settlement/ Commercial & & $\sqrt{ }$ & $\sqrt{ }$ & $\sqrt{ }$ & $\sqrt{ }$ \\
\hline Access to Basic Infrastructure & & $\sqrt{ }$ & $\sqrt{ }$ & & \\
\hline Access to Service Centre & & $\sqrt{ }$ & $\sqrt{ }$ & & \\
\hline Strategic Road Network & & $\sqrt{ }$ & & $\sqrt{ }$ & $\sqrt{ }$ \\
\hline Employment & & & $\sqrt{ }$ & $\sqrt{ }$ & \\
\hline Land Value & & & $\sqrt{ }$ & $\sqrt{ }$ & \\
\hline Proximity to Fault Line & & $\sqrt{ }$ & & $\sqrt{ }$ & \\
\hline Proximity to Stream Line & $\sqrt{ }$ & & & & $\sqrt{ }$ \\
\hline Soil Quality (Soil Fertility) & $\sqrt{ }$ & & & & $\sqrt{ }$ \\
\hline Air Quality (Dist. from Chimney) & & $\sqrt{ }$ & $\sqrt{ }$ & & \\
\hline $\begin{array}{l}\text { Noise Pollution (Dist. from Strategic } \\
\text { Road) }\end{array}$ & & $\sqrt{ }$ & & & \\
\hline Soil Erosion & $\sqrt{ }$ & & & & $\sqrt{ }$ \\
\hline Flood & & & & & $\sqrt{ }$ \\
\hline Heritage Landmark & & & & $\sqrt{ }$ & $\sqrt{ }$ \\
\hline Local Road Circulation & & & $\sqrt{ }$ & & \\
\hline Vegetation Index & & & & & $\sqrt{ }$ \\
\hline Soil Moisture Index & $\sqrt{ }$ & & & & \\
\hline Temperature & $\sqrt{ }$ & & & & \\
\hline Load Capacity/ Soil Strength & & & & $\sqrt{ }$ & \\
\hline Rainfall & $\sqrt{ }$ & & & & \\
\hline
\end{tabular}

(Source: Field survey, 2019) 


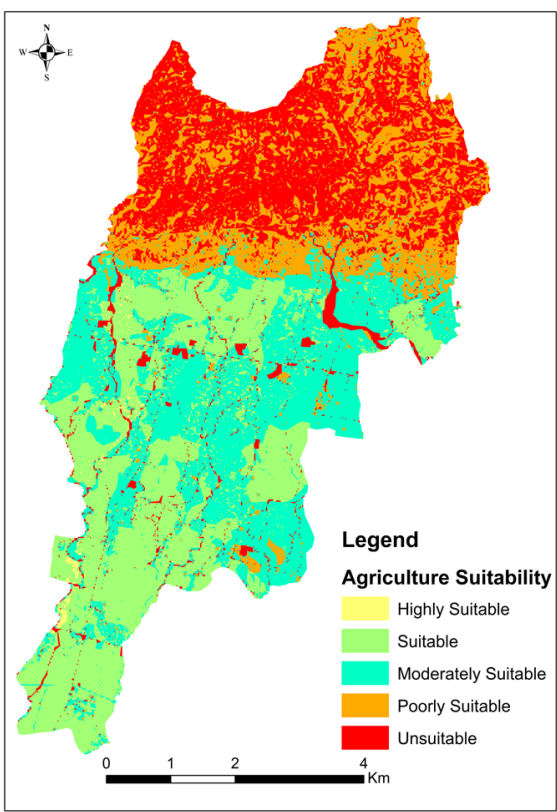

(a) Agriculture Use

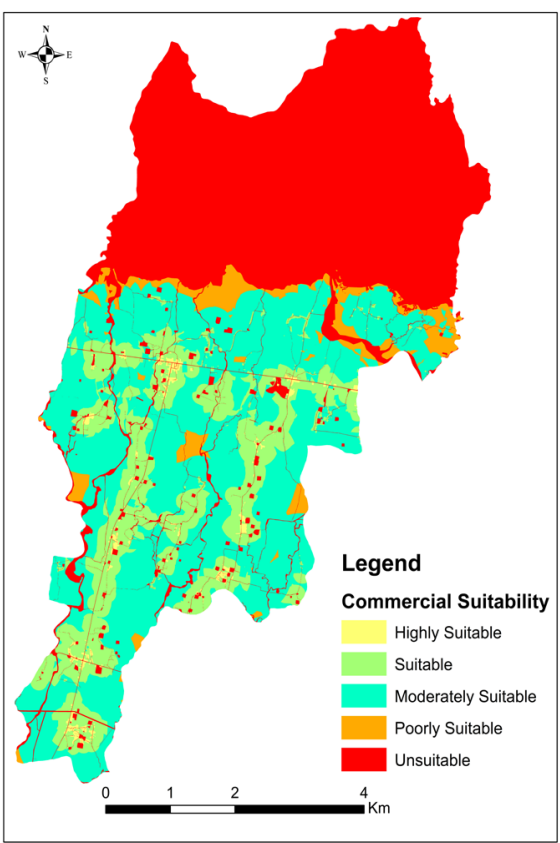

(c) Commercial Use

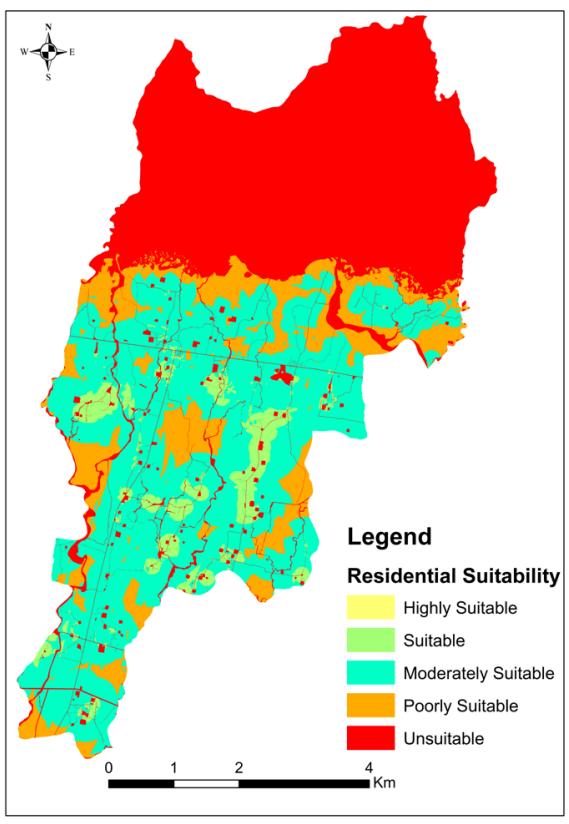

(b) Residential Use

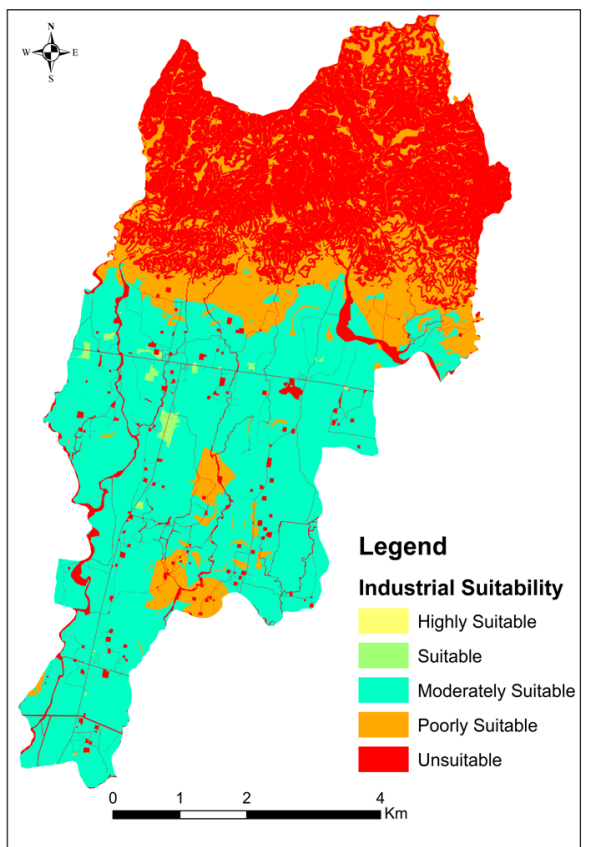

(d) Industrial Use 


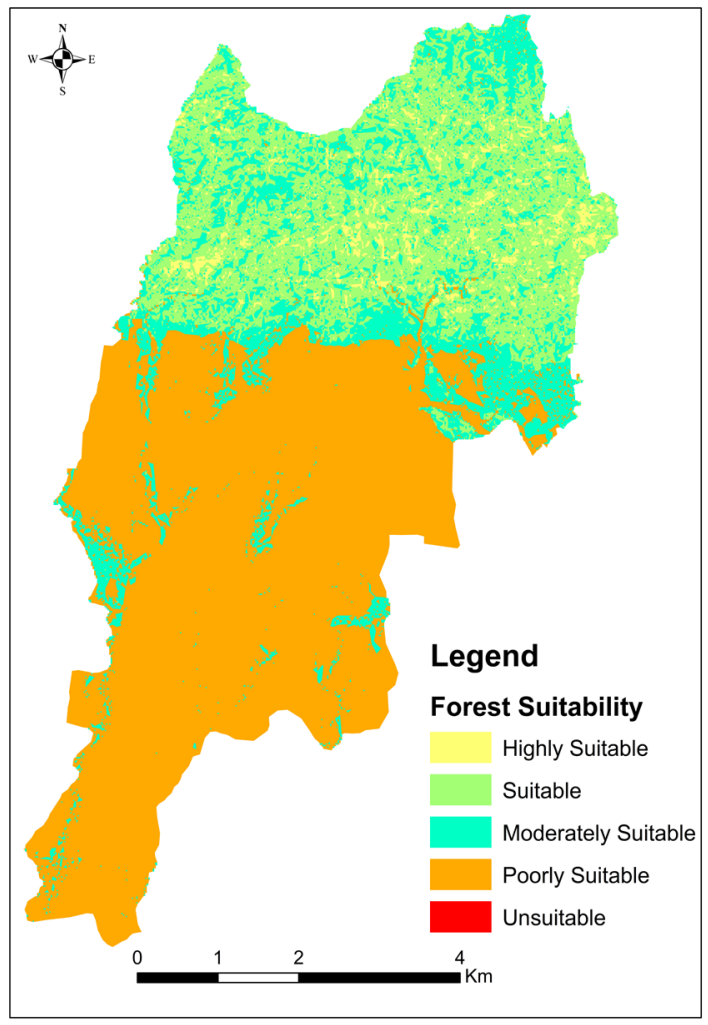

(e) Forest Use

Figure 2: Suitability Index for (a) Agriculture, (b) Residential, (c) Commercial, (d) Industrial, and (e) Forest Use in Sambhunath Municipality

The suitability index map for agriculture land use is shown in Figure 2(a). It indicates 3139 ha (29\%) agricultural land area within highly suitable, 3001 ha (28\%) agricultural land area within moderately suitable with and 2669 ha (25\%) agricultural land area within unsuitable category. However, the most of suitable agriculture land is found at low land with flat terrain and gentle slope, having high fertility rate and mainly in the land capability class I and II. The unsuitable and poorly suitable agricultural lands are found in the undulating terrain areas mainly along and within the Siwalik hill.

The suitability index map for residential land use is shown in Figure 2(b). It indicates that only 0.19 ha areas of the municipality are within highly suitable category, 527 ha (5\%) within suitable, 4108 ha (38\%) under moderately suitable category. The suitable residential land is occupied mainly along the road network of urban area and surrounding the existing settlements mainly in the rural area. 
The suitability index map for commercial land use is shown in Figure 2(c). It indicates that only 91 ha (about 1\%) areas are highly suitable for commercial use, 1690 ha $(16 \%)$ is under suitable and 3797.80 ha $(35 \%)$ areas are within moderately suitable for commercial use in the municipality. The highly suitable commercial lands are located along the East-west highway, feeder roads and surroundings of existing commercial area. In the rural areas, the suitable commercial land is found along the junctions of the road networks.

The suitability index map for industrial land use is shown in Figure 2(d) where 61 ha $(0.56 \%)$ is under suitable and $5143 \mathrm{ha}(47 \%)$ is under moderately suitable category for industrial use in the municipality. Most of the suitable industrial areas located along the East-west highway, feeder roads and surrounding the existing commercial areas. Categorically the most appropriate location for industrial use are situated near Devdhar along East-west highway, the north of the Rupani Bazar at the foot of Chure hill and at the barren land near Khando river, and south west of Kathauna Bazar area.

The suitability index map for forest land use is shown in Figure 2(e). It shows that 376 ha $(3.5 \%)$ is under highly suitable, 2810 ha $(26 \%)$ under suitable, 1835 ha (17\%) under moderate suitable for forest area in the municipality. The suitable and highly suitable forest areas are located in Siwalik hill and moderate suitable land for forest area have been identified surrounding to the river course within the municipality.

\section{Physical infrastructure plan}

Physical infrastructures are pre-requisite for the development of an area. Present study has conceptualized the guided physical infrastructures in relation to the strategic goals and development targets that are prerequisites for land use planning. The guided physical infrastructures are considered based on the "primary economic drivers" which could be central to the economic growth and social development in future particularly with a long term vision of 20 years to achieve a stable and diversified economy; enhanced human development and improved quality of life; environmentally sustainable and with strategies of mitigation of disasters; efficient, responsive and accountable system of governance; and appropriate land development for local people. Keeping physical infrastructure plan of DUDBC (2013) in mind, attempts have been made here to prepare physical infrastructure plan in order to cater the social need to develop the area (urban and rural environment) with improvement in quality of life within the municipality particularly to meet the demand of estimated population of about 51,000 in 2037 A.D. 
The demand for renewal land (for potential residential and commercial area) is derived from population projection for demands of land for housing due to the natural population growth, migration as well as increasing rates of urbanization, changes in income status, stage of economic growth and change in land productivity. The renewal land is required to meet the basic physical infrastructure for economic, environmental, historic and social values. Road infrastructures are designed by connecting with each and every land plot along and across the designed roads. Location of such services facilities are proposed in such way that minor adjustments required within road networks. Service facilities cover the sewerage, storm water drain, water supply lines, electricity poles, telecommunication cables etc. (Table 7).

Table 7: Infrastructure development status/plan

\begin{tabular}{|c|c|c|c|c|c|}
\hline S.N. & Description & Unit & Existing & Proposed & Total \\
\hline \multirow[t]{9}{*}{1} & Transportation & & & & \\
\hline & Highway & $\mathrm{Km}$ & 9.18 & - & 9.18 \\
\hline & Feeder Road & $\mathrm{Km}$ & 10.02 & - & 10.02 \\
\hline & District Road & $\mathrm{Km}$ & 9.67 & - & 9.67 \\
\hline & Agriculture Road & $\mathrm{Km}$ & 20.58 & 5.25 & 25.83 \\
\hline & Local Road & $\mathrm{Km}$ & 18.48 & 30.88 & 49.36 \\
\hline & Other Road & $\mathrm{Km}$ & 65.46 & 109.12 & 174.58 \\
\hline & Bridge & No. & 7 & 11 & 18 \\
\hline & Bus Park & No., ha & - & 1,2 & 1,2 \\
\hline 2 & Water supply & $\mathrm{km}$ & 3.25 & 35.81 & 39.06 \\
\hline \multirow[t]{4}{*}{3} & Sewerage \& Sanitation Work & & & & \\
\hline & Surface Drainage \& Sewerage & $\mathrm{km}$ & 7.55 & 175.35 & 182.90 \\
\hline & Sanitation & $\mathrm{km}$ & - & 18.40 & 18.40 \\
\hline & Landfill Site & No., ha & & 2,10 & 2,10 \\
\hline 4 & Electricity & $\mathrm{Km}$ & 88.17 & 32.04 & 120.21 \\
\hline 5 & $\begin{array}{l}\begin{array}{l}\text { Telecommunication (network \& } \\
\text { exchange) }\end{array} \\
\end{array}$ & Km, No. & $1.5 \& 0$ & $17.5 \& 1$ & $19.0 \& 1$ \\
\hline \multirow[t]{6}{*}{6} & Educational Institution & & & & \\
\hline & Primary & No. & 26 & 18 & 44 \\
\hline & Secondary & No. & 7 & 8 & 15 \\
\hline & Campus & No. & - & 1 & 1 \\
\hline & Polytechnic & No. & - & 1 & 1 \\
\hline & Library & No. & - & 3 & 3 \\
\hline \multirow[t]{4}{*}{7} & Health Institution & & & & \\
\hline & Health Post & No. & 3 & 5 & 8 \\
\hline & Primary Health Centre & No. & - & 1 & 1 \\
\hline & Hospital & No. & - & 1 & 1 \\
\hline
\end{tabular}




\begin{tabular}{|c|c|c|c|c|c|}
\hline \multirow[t]{4}{*}{8} & Social Services & & & & \\
\hline & Old age home & No. & - & 1 & 1 \\
\hline & Orphanage & No. & - & 1 & 1 \\
\hline & Institution Building & No. & 5 & 9 & 14 \\
\hline \multirow[t]{4}{*}{9} & Economic Infrastructur & & & & \\
\hline & Multipurpose Hall & No. & - & 1 & 1 \\
\hline & Commercial Centre & No. & - & 3 & 3 \\
\hline & Vegetable Market & No. & 1 & 2 & 3 \\
\hline \multirow[t]{4}{*}{10} & Security Services & & & & \\
\hline & Police Station & No. & - & 1 & 1 \\
\hline & Police Post & No. & 3 & 2 & 5 \\
\hline & Fire Station & No. & - & 1 & 1 \\
\hline \multirow[t]{4}{*}{11} & Recreation Activities & & & & \\
\hline & Playground & No., ha & $2,1.3$ & $13,13.2$ & $15,14.5$ \\
\hline & Parks \& Picnic Sports & No., ha & $2,11.1$ & $8,116.5$ & $10,127.6$ \\
\hline & Open space & No., ha & $21,4.1$ & $24,6.7$ & $45,10.8$ \\
\hline
\end{tabular}

\section{Land use plan}

Projected land use for year 2037 is simulated using CA modeling from existing land use map 2017 as base data with land use suitability index maps as parameters, and $5 \times 5$ contiguity filter. The generated land use plan is incorporated with risk layers and developments of physical infrastructure plan using subjective judgments as well as interactions with local stakeholders. The projection land use and development infrastructure relationship are interrelated with one another. The numbers of iteration work is conducted until the projection of one and another iteration process lies within the threshold limit of 0.05 (with $95 \%$ confidence level) through cross validation. The integrated land use plan is qualitatively optimized through SWOT analysis process, preserving the strength and opportunity as well as incorporating the weakness and minimizing the threats. All the qualitative information are incorporated in the integrated land use plan as shown in Figure 3. 


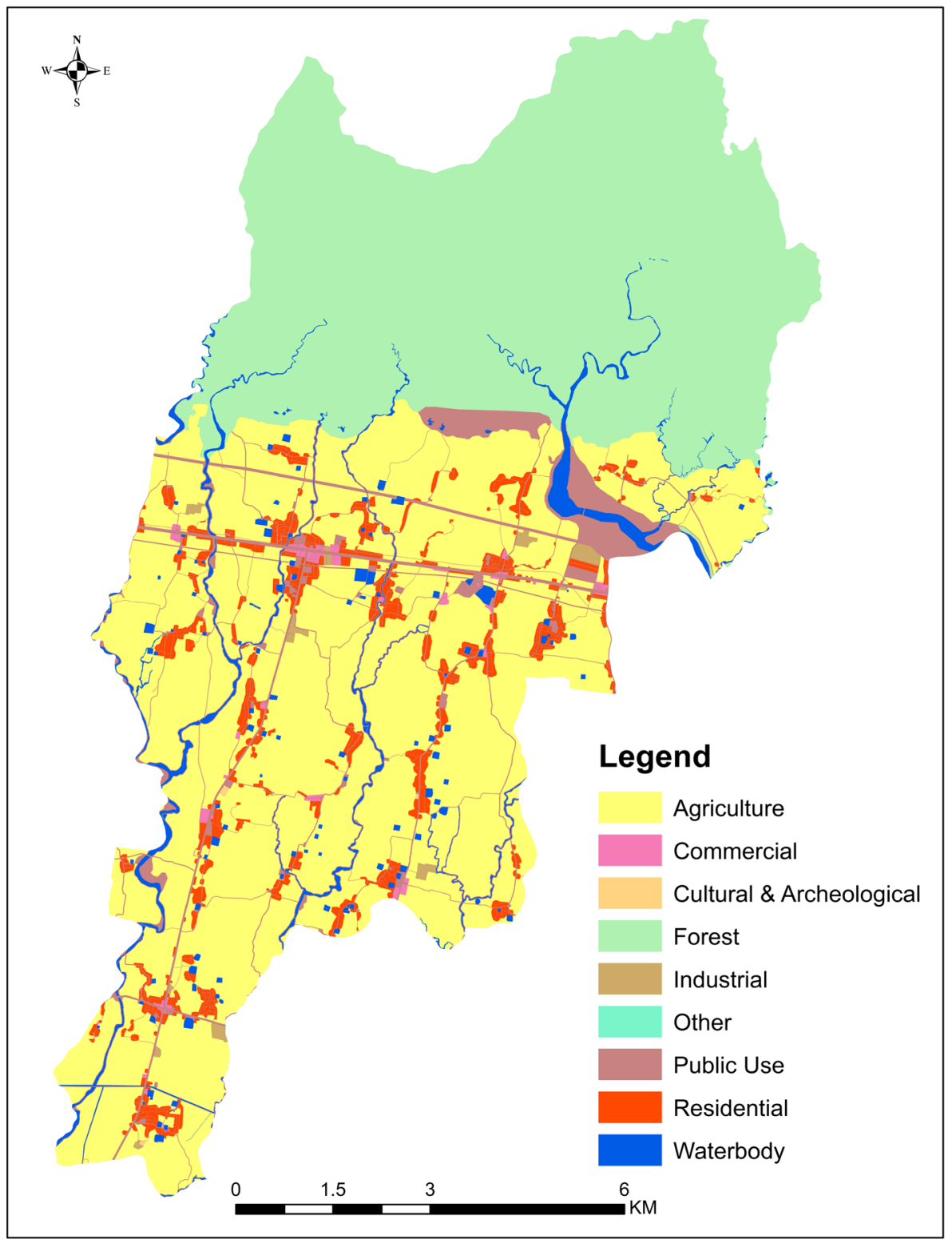

Figure 3: Land use plan

In land use plan for 2037, though the agriculture land use dominates with 5034 ha (46\% of the total extent of the municipality) but it is less than the existing agriculture areas of 2017. There is a decrease of 575 ha agriculture land in proposed land use plan. The 
agriculture land is allocated in the areas of high soil fertility level lowland with proper sufficient drainage particularly in areas of land capability class I and II surrounding to the residential area and water bodies. The up lands having high fertility and high capability have been allocated as potential horticulture land.

However, there is an increase of $201 \mathrm{ha}$ in residential land use within safe areas from different risks as well as in areas having sufficient physical infrastructures, social service and security service area. The commercial area (26ha) and industrial area (3ha) have been allocated additionally along the major strategic road networks for trade and business activities with appropriate public service area, security service area and other facilities as bank and financial institutions. The forest suitable land has been planned within undulating terrains of Siwalik hill and areas surrounding to the river course for protecting the soil erosion and conserving the environment. The proposed forest land is the second dominant land use with $40 \%$ of the municipality coverage having 4352 ha and existing 51 ha of the forest lands have been reserved for public use as picnic sport, construction dam for conserving slope stability and soil erosion.

\section{Land use implementation strategy}

Implementation strategies are designed on the basis of existing legal provision of Nepalese context with reference of international practices. The legal provision of land right and its spatial information is related with cadastral datasets and land records. So, the optimal land use plan is overlaid on the seamless cadastral maps in PBCI system and transferred the land use class as land use zone into the specific cadastral parcel. Based on the cadastral parcel record, these transferred land use data are linked correctly and accurately with the land tenure record and related other land information for systematic land use management in urban-rural economic development. Likewise, the development code is designed for construction of development infrastructure for land development. The construction permit is permitted based on the developing code for construction of any construction either public or private. Without the construction permit, any infrastructure or building should not be constructed in the municipality for proper land use. If constructed without prior permission from authority; the authority will immediately destroyed such infrastructure and building. Land use changes should be converted with grant permission from the local level land use implementation council. The monitoring mechanism is also developed for the implementation of land use plan in ground reality and to control the land use changes. Implementation strategy is empowered a framework for enforcement of compliance of land use zone and penalties for noncompliance. Formulated land use implementation strategy is used as guided land development activities to implement land use plan at local level. 


\section{Conclusion}

The geospatial techniques associated with quantitative tools which have been used for the analysis of spatial pattern of land use, land use changes, future trend of land use, densification and scatterings of built-up area. It is found to be very useful. Land use changes are taking place rapidly mainly surrounding to the infrastructure developed areas and in nearby existing settlements. Hence, infrastructure development has been playing a significant role as driving factor in land use change.

The criteria for the analysis of land evaluation have been identified from the literatures. These criteria were used for the land use suitability analysis as agriculture, residential, commercial, industrial, and forest within Sambhunath municipality of Nepal. The present study has found GIS integrated with MCE-AHP based on quantitative technique relevant for land suitability analysis more appropriate to evaluate the land quality assessment and to use in land use planning. Land use plan with favorable situation for the allocation of lands in appropriate use and developing economic value, physical infrastructure and inclusion of risk layers. These could be tested for the strength and opportunity as well as with considering the weakness and minimizing the threats.

The proposed land use plan follows the basic assumption of Hoyt's theory of land use and sustainable planning process. The implementation strategy has been developed based on the legal provisions of Nepalese context and international practices. The formulated strategies are suggested as the guidelines for land development, and to implement land use plan at local level. The present study found AHP technique very much appropriate to determine weight with the relative importance of the decision makers view, and an easier method to understand for all stakeholder's involvement in land use planning.

\section{References}

ADPC (2015). Disaster recovery toolkit, Asian disaster preparedness centre (ADPC) for the tsunami global lessons learned project. Available at: https://adpc.net/ igo/category/ID808/doc/2015-e3 Yk05 -ADPC-tglllivelihood.pdf. Accessed on: $25^{\text {th }}$ January, 2017.

Awasthi, P. R. (2019). A relationship between natural disaster and poverty. Journal of APF Command and Staff College, 2(1): 67-69.

Boakye, E., Anornu, G. K., Quaye-Ballard, G. A. \& Donkor, E. A. (2018). Land use change and sediment yield studies in Ghana: Review. Journal of Geography and Regional Planning, 11(9):122-133. 
Cruden, D. M. (1991). A simple definition of a landslide. Bulletin of the International Association of Engineering Geology, 43: 27-29.

Dodgson, J., Spackman, M., Pearman, A. \& Phillips, L. (1999). DTLR multi-criteria analysis manual. National Economic Research Associate (NERA). Available at: https:// nera.com/content/dam/nera/publications/archive2/Multi-criteria Analysis_Model.pdf. Accessed on: $16^{\text {th }}$ July 2016.

DUDBC (2013). Planning norms and standards. Department of Urban Development and Building Construction. Available at: https://dudbc.gov.np/uploads/default/ files/11 fc96 caa8c2194ab728796 d5e9144cd.pdf. Accessed on: 21 ${ }^{\text {st }}$ April, 2018.

FAO (1976). A framework for land evaluation. Soil Bulletin Vol. 32. Food and Agriculture Organization of United Nations, Rome.

FAO (1995). The state of food and agriculture. FAO Development Series 28. Food and Agriculture Organization of United Nations, Rome.

GIZ (2011). Land use planning: Concept, tools and applications. Land Policy and Land Management. Deutsche Gesellschaft für Internationale Zusammenarbeit. Eschborn, Germany.

Hao, W. (2013). A GIS-based framework for supporting sustainable land use planning in urban renewal projects. Ph.D. Dissertation. The Hong Kong Polytechnic University. Hung Hom, Kowloon, Hong Kong, China.

Ishizaka, A., Lolli, F., Gamberini, R., Rimini, B. \& Balugani, E. (2017). AHP-K-GDSS: A new sorting method based on AHP for group decisions. Proceedings of the Int. Conference on Modeling and Applied Simulation. Available at: https://iris. unimore.it/retrieve/handle/11380/1152794/269740/MAS2017_1.pdf. Accessed on: $20^{\text {th }}$ March, 2017.

Karna, B. K (2021). Land evaluation for land use planning in Sambhunath municipality of Saptari district, Nepal. Unpublished dissertation submitted to Dean's Office, FoHSS, Kirtipur: Tribhuvan University.

Karna, B. K., Shrestha, S. \& Koirala, H. L. (2021). Geo-information modeling of soil erosion for sustainable agriculture land management in Sambhunath municipality. Journal on Geoinformatics, Nepal, 20: 47-57.

Karna, B. K., Mandal, U. K. \& Bhardwaj, A. (2013). Urban sprawl modeling using RS and GIS technique in Kirtipur municipality. Nepalese Journal on Geoinformatics, 12:50-56. 
Khanal, N. R. (2000). Land use and land cover dynamics in the Himalaya: A case study of the Madi watershed, western development region, Nepal". Ph.D. Dissertation. Tribhuvan University, Nepal.

Koirala, P., Thakuri, S., Joshi, S. \& Chauhan, R. (2019). Estimation of soil erosion in Nepal using a RUSLE modeling and Geospatial tool. Geoscience, 9: 1-19.

Malczewski, J. (2004). GIS-based land use suitability analysis: A critical overview. Progress in Planning, 62: 3-65.

Mendas, A. \& Delali, A. (2012). Integration of multi-criteria decision analysis in GIS to develop land suitability for agriculture: Application to durum wheat cultivation in the region of Mleta in Algeria. Computer Electronic Agriculture, 83: 117126.

MoFAGA, (2018). Detail Description of Sambhunath Municipality: GIS Database. Ministry of Federal Affair and General Administration, Nepal.

Nigam, R. K. (2006). Application of remote sensing and geographical information system for land use/land cover mapping and change detection in the rural urban fringe area of Enschede City, The Netherlands. International Archives of Photogrammetry and Remote Sensing, 37(B7):993-998.

Schreinemachers, P. \& Berger, T. (2006). Land use decisions in developing countries and their representation in multi-agent systems. Journal of Land Use Science, 1(1):29-44.

Seyedeh, Z. M., Ataollah, K., Karim, S., Seyed, R. M. \& Ataollah, S. (2011). GIS-based spatial prediction of landslide susceptibility using logistic regression model. Geomatics, Natural Hazards and Risk, 2(1): 33-50.

Veit, P. (2011). Placing land rights at the heart of development. History of Land Conflicts in Kenya. Available at: http://www.focusonland.com/download 076c59cca75. Accessed on: $13^{\text {th }}$ June, 2016.

Verheye, W. H. (2009). Land use, land cover and soil science. Land Use planning, Vol.3. Eolss Publication Ltd. Oxford. United Kingdom.

Widiatmaka W. (2016). Integrated use of GIS, AHP and remote sensing in land use planning for tropical high altitude vegetable crops. Journal of Applied Horticulture, 18:87-99.

Ziadat, F. M. \& Al-Bakri, J. T. (2006). Comparing existing and potential land use for sustainable land utilization. Jordan Journal of Agricultural Sciences, 2(4): 372386. 